\title{
Factors Impacting Hospital Financial Performance in Taiwan Following Implementation of National Health Insurance
}

\author{
Jiunn Chiou Chiang ${ }^{1}$, Tsai Yi Wang ${ }^{1}, \&$ Feng Jui $\mathrm{Hsu}^{2}$ \\ ${ }^{1}$ National Taichung University of Science and Technology, Taiwan \\ ${ }^{2}$ National Chung Hsing University, Taiwan \\ Correspondence: Tsai Yi Wang, National Taichung University of Science and Technology, No.129, Sec. 3, \\ Sanmin Rd., North Dist., Taichung City 40401, Taiwan. Tel: 886-4-2219-5922. E-mail: peterw@nutc.edu.tw
}

Received: November 18, 2013

Accepted: November 25, 2013

Online Published: January 23, 2014

doi: $10.5539 /$ ibr.v7n2p43

URL: http://dx.doi.org/10.5539/ibr.v7n2p43

\begin{abstract}
This research discusses factors influencing hospital performance following the implementation of Taiwan's National Health Insurance scheme. Regression analysis showed that the out-patient revenue ratio and fixed assets ratio were significantly and positively associated with operating margin and return on fixed assets. Liability conditions and average length of stay were negatively associated with operating margin. Return on fixed assets was positively associated with the use of hi-tech equipment and negatively associated with average length of stay. Implications of findings and recommendations to improve the performance of Taiwan hospitals are discussed.
\end{abstract}

Keywords: hospital performance, national health insurance, Taiwan

\section{Introduction}

In 1995, Taiwan implemented a National Health Insurance (NHI) scheme, stimulating competition in the health care market. Taiwan hospitals are categorized by type (medical center, teaching hospital, regional hospital, and district hospital) and region (north, middle, south and east). Since the implementation of NHI, out-patient attendance at large hospitals has decreased significantly, and small hospitals are having increased difficulty competing with larger medical centers. Hospital financial and operating performance can have an important effect on the role-effectiveness of various sizes and levels of hospitals to provide effective and efficient health care in Taiwan.

In 1995, Taiwan had 715 hospitals, including 12 medical centers, 42 regional hospitals, 86 district teaching hospitals, 475 district hospitals, 3 speciality teaching hospitals, 9 psychiatric teaching hospitals, 18 psychiatric hospitals, and 92 other miscellaneous institutions (Sources: Hospitals Accreditation Report, FY's 1993, 1994, and 1995, Department of Health, Government of Taiwan, ROC; Accreditation of Psychiatric Hospitals Report, FY 1994, DOH). Prior to the implementation of the NHI scheme on March 1, 1995, public health insurance programs in Taiwan included three separate schemes for farmers, labors, and government employees, but $25 \%$ ( 5 million people) of the population was not covered by either these schemes or private insurance. NHI was implemented to provide blanket coverage, with a special emphasis on children, the elderly and the poor who were currently without health insurance. The scheme was financed in part by doubling the premiums of those already covered by the three public schemes.

The medical environment in Taiwan differs from that in many Western countries, along with the primary issues in hospital financial management. The following discussion reviews the key characteristics of Taiwan's medical system, including payments, fees and insurance.

Taiwan's NHI system features three types of doctor's wage and salary systems. The first, typical of large private hospitals, is a fee-for-service system established 30 years ago to raise doctor incomes, improve service quality, and reduce the incidence of bribery. This system has been modified to the current physician fee (PF) system, wherein doctors receive $1 \%$ of the hospital's fees for examination, handling and surgery as a bonus. Since doctor incomes are determined by patient volume and price of service items, this system encourages doctors to treat more patients and provide higher-priced services. According to Lin (1994), prior to the implementation of NHI $57.5 \%$ of regional hospitals used the physician fee system. The second physician compensation system is the salary plus bonus system used in public hospitals, where doctors are paid a bonus based on hospital profitability. 
This system encourages doctors to help the hospital control costs, fixed fee standards and controlled factors which impacted the market for medical services. The third system is the individual profit system in small private clinics where doctor incomes are determined by the hospital profits, encouraging doctors to help increase hospital income and reduce costs.

In terms of fees and insurance payments, $80 \%$ of hospital income comes from the Bureau of National Health Insurance through patient claims (known as "written declarations"). The remaining $20 \%$ comes from registration fees, copays, and minority difference burdens - government subsidies for people below poverty line and poor indigenous populations to cover the $20 \%$ copay. The Healthcare Bureau strictly regulates the list of declarable items and conducts critical audits of medical services and expenses to prevent waste and reduce increases to the overall cost of medicine. The declaration is also involved in the management of hospital accounts receivable. Increased attention should focus on increasing declared expenses, raising the ratio of pre-paid fees, accelerating payments, and reducing the number of rejected declarations.

Using operating margin and ROA as profit rate, Cleverley and Harvey (1992) found that hospitals providing lower quality medical services have relatively lower profit rates, service charges, patient costs, asset/income ratios, and patient recovery rates. Pike (1984) suggested that company scale, risk and performance are positively correlated after controlling company scale. In addition, average inpatient days is a better indicator for predicting operating margins, while the expansion of operating margins in AMI and HCA was attributed to change in the case-mix. Thus, inpatient status is the key path to achieving high operating margins (Sear, 1992). Following the studies mentioned above, here we focus on operating margin and return on fixed assets to assess the influence of profitability factors.

\section{Method}

The data for this study was gathered from hospital financial statements filed with the National Health Insurance Bureau. The 144 public and private hospitals in the sample represented $23.8 \%$ of Taiwan's total hospitals, with a total of 45,014 beds (48.2\% of Taiwan's total bed capacity), far exceeding the sample size of most previous studies on hospital financial effectiveness and status. The database was created using BASE IV and data from the Taiwan National Health Department (NHD) database for analysis in SAS. The NHD sources data from each hospital which is then standardized and converted to an SAS-compatible format. Statistical analysis methods were selected according to the study objectives and hypotheses. The financial data file contained balance sheets and income statements of 12 hospitals for the fiscal year January 1 to December 31 . To assess factors affecting hospital financial performance, simple linear regression was carried out using a single independent variable and a hospital financial performance indicator as the dependent variable, followed by addition of variables to assess factors influencing the dependent variable after controlling for other variables. Furthermore, multiple regression analysis was performed using operating margin and return on fixed assets (i.e., measures of hospital profitability) as continuous dependent variables. Geographic location, hospital size as measured by bed capacity, hospital ownership, outpatient revenue ratio, inpatient surgery rate, other revenue ratio, fixed asset rate, liability conditions, amount of hi-tech equipment installed, and average length of stay were used as independent variables.

Public hospitals have a system of offsetting operating income through increased capital depreciation for fiscal years with better operating performance, thus providing increasing budgets and employee bonuses, (and vice versa during poor performance years). To ensure the comparability of data for private and public hospitals, we created a variable for adjusted operating margin. Using operating margin as the dependent variable, the results of multiple regression are presented in the following model:

Operating margin $=-0.079+0.918$ (outpatient revenue) +0.185 (fixed assets proportion) -0.127 (liability) 0.002 (average of day inpatient)

Similarly, the return on fixed assets was adjusted for public hospitals, and the regression yielded the following model:

Return on fixed assets $=-1.362+3.924$ (outpatient revenue) -3.101 (fixed assets rate) +1.859 (with 1 or 2 hi-tech equipment) - 0.038 (average length of stay)

\section{Results}

Our results are presented in two sections. The first section on descriptive statistics describes the hospital sample. The second section deals with multivariable analyses to assess the association of the independent variables of interest with the dependent variables to address study hypotheses, after controlling for the effect of control variables. 


\subsection{Descriptive Statistics}

The sample includes 144 hospitals, including 67 public hospitals, 49 private hospitals and 28 hospitals run by charitable foundations. The sample represents $79 \%$ of all public hospitals (67 of 84 ), $47.5 \%$ of charitable foundation hospitals ( 28 of 59), and $10.6 \%$ of private hospitals (49 of 462).

The sampled hospitals include 10 medical centers, 22 regional hospitals and 112 district hospitals, respectively representing $71.4 \%, 48.9 \%$ and $20.5 \%$ of all hospitals in each class (see Table 1). In terms of geographic distribution, 66 of the sample hospitals were in the south region, followed by 50 in the north, 21 in the central region, and 7 in the east, respectively representing $24.4 \%, 23.2 \%, 20 \%$ and $50 \%$ of all hospitals in each region.

In terms of capacity, the sample included 60 hospitals with fewer than 100 beds, 35 with 100-299 beds, 22 with $300-499$ beds, 20 with 500-999 beds, and 7 with more than 1000 beds, respectively accounting for $14.4 \%, 35 \%$, $53.7 \%, 55.6 \%$, and $63.6 \%$ of hospitals in each size range.

Table 1. Distribution of sample hospitals by general characteristics

\begin{tabular}{|c|c|c|c|c|}
\hline & Total Hospital & Sample \# & Percent & Statistic value \\
\hline \multicolumn{5}{|l|}{ Type of Hosp. } \\
\hline Public & 84 & 67 & $79.80 \%$ & \multirow{3}{*}{$\mathrm{X}^{2}=101.44^{*}$} \\
\hline Private & 462 & 49 & $10.60 \%$ & \\
\hline Foundation & 59 & 28 & $47.50 \%$ & \\
\hline \multicolumn{5}{|l|}{ Level of Hosp. } \\
\hline Medical Center & 14 & 10 & $71.40 \%$ & \multirow{3}{*}{$X^{2}=17.83^{*}$} \\
\hline Regional Hosp. & 45 & 22 & $48.90 \%$ & \\
\hline District Hosp. & 546 & 112 & $20.50 \%$ & \\
\hline \multicolumn{5}{|l|}{ Region } \\
\hline North & 216 & 50 & $23.20 \%$ & \multirow{4}{*}{$\mathrm{X}^{2}=3.29$} \\
\hline Central & 105 & 21 & $20 \%$ & \\
\hline South & 270 & 66 & $24.40 \%$ & \\
\hline East & 14 & 7 & $50 \%$ & \\
\hline \multicolumn{5}{|l|}{ Bed capacity } \\
\hline$<100$ Beds & 417 & 60 & $14.40 \%$ & \multirow{5}{*}{$X^{2}=41.75^{*}$} \\
\hline 100-299 Beds & 100 & 35 & $35 \%$ & \\
\hline 300-499 Beds & 41 & 22 & $53.70 \%$ & \\
\hline 500-999 Beds & 36 & 20 & $55.60 \%$ & \\
\hline$>1000$ Beds & 11 & 7 & $63.60 \%$ & \\
\hline Mean Bed capacity & 154.5 & 312.6 & & $\mathrm{t}=0.55$ \\
\hline Total Hospital & 605 & 144 & $23.80 \%$ & \\
\hline Total Beds & 93742 & 45014 & $48.20 \%$ & \\
\hline
\end{tabular}

Note: * denotes Z-value significance at 5\%. 2. Significance level = 0.05. 3. Sample \# denotes number of hospitals.

\subsection{Multivariable Analyses}

The operational characteristics studied in this research include product and management characteristics. The product characteristics include the proportion of outpatient revenue to total hospital revenue, and the inpatient surgery rate. Management characteristics include the ratio of other revenues to total revenues, fixed assets ratio, asset used ratio, liability status, average length of stay, and amount of hi-tech equipment installed. Table 2 presents the mean and standard deviations of the sample hospitals in terms of these characteristics. 
Table 2. Descriptive statistics of hospital operational characteristics

\begin{tabular}{|c|c|c|c|c|}
\hline Research Variable (Average \pm S.D.) & \multicolumn{4}{|c|}{ Type of Hospital } \\
\hline & Total & Public & Private & Foundation \\
\hline \multicolumn{5}{|l|}{ Product Mix } \\
\hline Outpatient Revenue \% Ratio & $53.89 \pm 18.27$ & $48.96 \pm 16.56$ & $64.71 \pm 7.83$ & $6.76 \pm 14.34$ \\
\hline Inpatient Surgery (\%) Rate & $30.63 \pm 40.28$ & $35.14 \pm 53.1 \%$ & $23.32 \pm 24.26$ & $30.92 \pm 14.95$ \\
\hline \multicolumn{5}{|l|}{ Management Characteristics } \\
\hline Other Revenue (\%) & $2.48 \pm 5.87$ & $3.60 \pm 8.06$ & $0.33 \pm 0.83$ & $3.55 \pm 3.18$ \\
\hline Fixed Assets (\%) & $43.72 \pm 31.09$ & $26.69 \pm 25.29$ & $59.44 \pm 31.28$ & $57.54 \pm 21.47$ \\
\hline Assets Used Years & $3.03 \pm 3.03$ & $3.28 \pm 2.49$ & $2.99 \pm 4.01$ & $2.41 \pm 1.95$ \\
\hline Liability Condition & $0.37 \pm 0.34$ & $0.29 \pm 0.19$ & $0.49 \pm 0.48$ & $0.32 \pm 0.22$ \\
\hline Average length of stay & $19.27 \pm 57.13$ & $30.62 \pm 80.11$ & $8.61 \pm 2.93$ & $7.70 \pm 2.34$ \\
\hline Occupancy Rate & $65.07 \pm 25.05$ & $64.66 \pm 22.13$ & $62.37 \pm 31.95$ & $70.66 \pm 17.41$ \\
\hline High Tech. Equip. & $1.97 \pm 4.29$ & $2.19 \pm 4.82$ & $0.88 \pm 3.17$ & $3.36 \pm 4.29$ \\
\hline 0 Unit & {$[68(47.2 \%)]$} & {$[24(35.8 \%)]$} & {$[37(75.5 \%)]$} & {$[7(25.0 \%)]$} \\
\hline 1-2 Units & {$[52(36.1 \%)]$} & {$[31(46.3 \%)]$} & {$[10(20.4 \%)]$} & {$[11(39.3 \%)]$} \\
\hline \multirow[t]{3}{*}{$>3$ Units } & {$[24(16.7 \%)]$} & {$[12(17.9 \%)]$} & {$[2(4.1 \%)]$} & {$[10(100 \%)]$} \\
\hline & \multicolumn{4}{|c|}{ Level of Hospital } \\
\hline & Medical Center & Regional Hosp. & District Hosp. & \\
\hline \multicolumn{5}{|l|}{ Product Mix } \\
\hline Outpatient Revenue (\%) & $37.36 \pm 8.89$ & $44.72 \pm 7.64$ & $57.17 \pm 18.98$ & \\
\hline Surgery Inpatient (\%) & $46.45 \pm 7.67$ & $33.15 \pm 13.94$ & $28.55 \pm 45.49$ & \\
\hline \multicolumn{5}{|l|}{ Management Characteristics } \\
\hline Other Revenue (\%) & $7.11 \pm 14.99$ & $2.13 \pm 1.78$ & $2.13 \pm 6.3$ & \\
\hline Fixed Assets (\%) & $48.15 \pm 20.21$ & $31.21 \pm 24.06$ & $45.80 \pm 32.66$ & \\
\hline Assets Useful Years & $4.08 \pm 2.22$ & $2.54 \pm 1.38$ & $3.02 \pm 3.30$ & \\
\hline Liability Condition & $0.14 \pm 0.13$ & $0.32 \pm 0.15$ & $0.39 \pm 0.37$ & \\
\hline Average length of stay & $10.77 \pm 1.83$ & $10.09 \pm 2.78$ & $21.96 \pm 64.95$ & \\
\hline Occupancy Rate & $84.65 \pm 7.65$ & $74.18 \pm 13.81$ & $61.54 \pm 26.57$ & \\
\hline High Tech. Equip. & $13.3 \pm 37.0$ & $3.36 \pm 3.08$ & $0.69 \pm 1.91$ & \\
\hline 0 set & {$[0]$} & {$[1(4.5 \%)]$} & {$[67(59.8 \%)]$} & \\
\hline $1-2$ sets & {$[0]$} & {$[11(50.0 \%)]$} & {$[41(36.6 \%)]$} & \\
\hline 3 sets over & {$[10(100 \%)]$} & {$[10(45.5 \%)]$} & {$[4(3.6 \%)]$} & \\
\hline
\end{tabular}

Note: S.D. denotes standard deviation.

Financial effectiveness includes measures of operating ability and profitability to provide insight into the hospital's overall financial condition (see Table 3). 
Table 3. Descriptive statistics of hospital financial performance

\begin{tabular}{|c|c|c|c|c|}
\hline \multirow[t]{2}{*}{ Panel A } & \multicolumn{4}{|c|}{ Type of hospital } \\
\hline & Total & Publics & Private & Person \\
\hline \multicolumn{5}{|l|}{ Operating Ability } \\
\hline Total Assets Turnover & 85.46 & 84.71 & 167.78 & 71.77 \\
\hline Fixed Assets Turnover & 320.13 & 570.38 & 394.09 & 126.20 \\
\hline Current Asset Turnover & 253.60 & 185.00 & 692.04 & 231.47 \\
\hline \multicolumn{5}{|l|}{ Profitability } \\
\hline Markup & 1.01 & 0.81 & 1.06 & 1.04 \\
\hline Operating Margin & -0.01 & -0.247 & 0.04 & 0.02 \\
\hline Total Margin & 0.00 & -0.197 & 0.04 & 0.01 \\
\hline Non-operating Rev. & 0.01 & 0.01 & 0.00 & 0.03 \\
\hline Return on Total Assets (\%) & -0.28 & -12.40 & 7.31 & 0.97 \\
\hline Return on Fixed Assets (\%) & -0.34 & -33.70 & 13.88 & 1.69 \\
\hline Profit/(FA-Land)(\%) & -0.79 & -67.54 & 11.78 & 2.05 \\
\hline Return on Equity (\%) & -1.92 & -21.50 & 11.68 & 1.80 \\
\hline \multicolumn{2}{|c|}{ Panel B } & \multicolumn{3}{|c|}{ Level of hospital } \\
\hline & Total & $\begin{array}{r}\text { Medical } \\
\text { Center }\end{array}$ & $\begin{array}{c}\text { Regional } \\
\text { Hosp. }\end{array}$ & District Hosp. \\
\hline \multicolumn{5}{|l|}{ Operating ability } \\
\hline Total Assets Turnover & 55.91 & 82.75 & 98.57 & 96.00 \\
\hline Fixed Assets Turnover & 119.22 & 499.99 & 323.14 & 175.00 \\
\hline Current Assets Turnover & 137.47 & 310.42 & 255.49 & 388.00 \\
\hline \multicolumn{5}{|l|}{ Profitability } \\
\hline Markup & 1.04 & 0.98 & 1.01 & 1.24 \\
\hline Operating Margin & 0.00 & -0.060 & 0.01 & 0.03 \\
\hline Total Margin & 0.02 & -0.036 & -0.009 & - \\
\hline Non-operating Rev. & 0.07 & 0.02 & 0.00 & 0.31 \\
\hline Return on total Assets (\%) & 2.56 & -5.30 & -0.49 & 5.00 \\
\hline Return on Fixed Assets (\%) & 7.75 & -7.70 & -0.62 & - \\
\hline Profit/(FA-Land) (\%) & 9.48 & -22.17 & -0.79 & - \\
\hline Return on Equity (\%) & 3.73 & -8.84 & -2.20 & 9.00 \\
\hline
\end{tabular}

Selection of indicators was based on: McCue, M. J. and Lynch, J. R., 1987.

Regression analysis showed that each unit increase in non-operating revenue is associated with a 0.9772 decrease in operating margin $(\mathrm{P}<0.01)$.

Liability conditions also showed a significant association with operating margin $(\mathrm{P}<0.05)$, and operating margin increases with the ratio of debt to total assets increases (regression coefficient $=0.2316$ ). Operating margin also decreased as average length of stay (also referred to as Average Days Inpatient or ADI) increased (regression coefficient $=-0.0031, \mathrm{P}<0.01)$. 
Table 4. Analysis of factors associated with operating margin (simple linear regression analyses)

\begin{tabular}{lccc}
\hline \multicolumn{1}{c}{ Variables } & Regression Analyses of Operating Margin & \\
\hline Independent variables & Mean \pm SE & Reg. Coefficients & SE \\
Outpatient Rev. & $53.89 \pm 18.27$ & 0.01 & 0.16 \\
Surgery rate & $30.63 \pm 40.28$ & 0.08 & 0.06 \\
Other Rev. & $2.48 \pm 5.87$ & $-0.9772 *$ & 0.50 \\
F.A rate & $43.72 \pm 31.09$ & 0.15 & 0.10 \\
Asset used yr. & $3.03 \pm 3.03$ & -0.01 & 0.01 \\
Li. cond. & $0.37 \pm 0.34$ & 0.23 & 0.09 \\
Ave. LOS & $19.27 \pm 57.13$ & $-0.0031^{* * *}$ & 0.01 \\
Inpatient rate & $65.07 \pm 25.05$ & 0.00 & 0.00 \\
\hline
\end{tabular}

Note: $*$ and $* * *$ respectively denote significance at $10 \%$ and $1 \%$.

Regression analysis showed that each unit increase in the fixed asset rate is associated with a 5.7814 point increase in return on fixed assets $(\mathrm{P}<0.01)$.

Increased ADI was found to correlated to decreased return on fixed assets (regression coefficient $=-0.0329$ ).

Table 5. Analysis of factors associated with return on fixed assets (simple linear regression)

\begin{tabular}{llcc}
\hline \multicolumn{1}{c}{ Variables } & & Regression Analyses for Return on Fixed Assets \\
\hline Independent Variable & Ave \pm SE & Reg. Coeff.. & S.E. \\
Outpatient Rev. & $53.89 \pm 18.27$ & $6.0649^{* *}$ & 2.3838 \\
Surgery Rate & $30.63 \pm 40.28$ & 0.7393 & 1.2268 \\
Other Rev. & $2.48 \pm 5.87$ & 4.322 & 7.4792 \\
F.A Rate & $43.72 \pm 31.09$ & $5.7814^{* * *}$ & 1.3518 \\
Asset used yr. & $3.03 \pm 3.03$ & 0.0416 & 0.1504 \\
Liability Condition & $0.37 \pm 0.34$ & -0.2873 & 1.3169 \\
ADI & $19.27 \pm 57.13$ & $-0.0329 * * *$ & 0.0079 \\
Inpatient Rate & $65.07 \pm 25.05$ & 0.0079 & 0 \\
\hline
\end{tabular}

Note: $* *$ and $* * *$ respectively denote significance at $5 \%$ and $1 \% .2$. Reg. Coeff denotes the regression coefficient.

In this model, outpatient revenue, fixed asset rate, liability condition, and average length of stay serve as significant predictors of adjusted operating margin. Outpatient revenue, and fixed asset rate were significant predictors of (adjusted) operating margin at the 0.05 level, being positively associated with operating margin. At the 0.01 level both average length of stay and liability condition were negatively associated with operating margin.

In the multiple regression, the regional or district hospital category was not significantly associated with adjusted operating margin or return on fixed assets. In addition, the other revenue variable (non-operating revenue) that was marginally significant in the unadjusted operating margin regression failed to attain significance when using adjusted margin. 
Table 6. Factors associated with adjusted operating margin — multiple regression results

\begin{tabular}{|c|c|c|c|c|}
\hline Variables & Beta & S.E & t-value & $P$ value \\
\hline Intercept & -0.08 & 0.12 & 0.65 & 0.52 \\
\hline \multicolumn{5}{|l|}{ Product mix } \\
\hline Outpatient Rev. & 0.20 & 0.08 & 2.46 & $0.01 * *$ \\
\hline Surgery rate & -0.05 & 0.05 & 0.98 & 0.32 \\
\hline \multicolumn{5}{|l|}{ Level } \\
\hline Regional Hosp & -0.14 & 0.10 & 1.34 & 0.18 \\
\hline District Hosp & -0.10 & 0.12 & 0.87 & 0.38 \\
\hline \multicolumn{5}{|l|}{ Management characteristics } \\
\hline Other Rev. . & 0.30 & 0.35 & 0.87 & 0.38 \\
\hline F.A rate & 0.19 & -0.08 & 2.34 & $0.02 * *$ \\
\hline Liability condition & -0.13 & 0.08 & 1.66 & $0.10^{*}$ \\
\hline HTE(1-2 sets) & 0.02 & 0.05 & 0.49 & 0.62 \\
\hline HTE(3 sets over) & 0.08 & 0.09 & 0.85 & 0.39 \\
\hline ADI & 0.00 & 0.00 & 3.56 & $0.00 * * *$ \\
\hline \multicolumn{5}{|l|}{ Geographic location } \\
\hline Central & 0.04 & 0.07 & 0.61 & 0.54 \\
\hline South & 0.05 & 0.05 & 1.01 & 0.31 \\
\hline $\mathrm{R}^{2}$ & 0.44 & & & \\
\hline Adjusted $\mathrm{R}^{2}$ & 0.38 & & & \\
\hline $\mathrm{F}$ value & & & 7.10 & $\mathrm{P}<0.0001$ \\
\hline
\end{tabular}

Note: $* * *$, and $* * *$ respectively denote significance at $10 \%, 5 \%$, and $1 \%$.

Table 7. Factors associated with adjusted return on fixed assets - multiple regression results

\begin{tabular}{|c|c|c|c|c|}
\hline Independent variable & Beta & S.E & t-value & P-value \\
\hline Intercept & -1.36 & 2.62 & 0.52 & 0.60 \\
\hline \multicolumn{5}{|l|}{ Product mix } \\
\hline Outpatient Rev. & 3.92 & 1.75 & 2.24 & $0.02 *$ \\
\hline Surgery rate & 0.03 & 1.07 & 0.03 & 0.98 \\
\hline \multicolumn{5}{|l|}{ Level } \\
\hline Regional Hosp. & -0.08 & 2.23 & 0.03 & 0.97 \\
\hline District Hosp. & -1.16 & 2.52 & 0.46 & 0.64 \\
\hline \multicolumn{5}{|c|}{ Management characteristics } \\
\hline Other Rev. & -1.43 & 7.50 & 0.19 & 0.84 \\
\hline F.A rate & -3.10 & 1.71 & 1.81 & $0.07 *$ \\
\hline Liability condition & 1.62 & 1.67 & 0.97 & 0.33 \\
\hline HTE(1-2 sets) & 1.86 & 1.06 & 1.76 & $0.08 *$ \\
\hline HTE(3 sets over) & 1.05 & 1.99 & 0.53 & 0.59 \\
\hline ADI & -0.04 & 0.01 & 4.17 & $0.00 * * *$ \\
\hline Geographic location & & & & \\
\hline
\end{tabular}




\begin{tabular}{lccc}
\hline Central & 1.68 & 1.49 & 1.13 \\
South & 0.14 & 1.05 & 1.08 \\
$\mathrm{R}^{2}$ & 0.3083 & & \\
Adjusted $\mathrm{R}^{2}$ & 0.23 & \\
$\mathrm{~F} \quad$ value & & $3.937 \quad \mathrm{P}<0.0001$ \\
\hline
\end{tabular}

Note: *, **, and $* * *$ respectively denote significance at $10 \%, 5 \%$, and $1 \%$.

\section{Discussion and Conclusion}

\subsection{Operating Margin}

Fixed assets showed a significant positive association with operating margin. When the debt variable is significant, reported profitability declines due interest payments and other debt-related costs, leading to a negative correlation between debt and profitability. Survey data show that Taiwan hospitals generally carry low levels of debt, and thus enjoy greater profitability. As the ratio of debt to total assets increases by $10 \%$, operating margin declined $1.27 \%$.

Under the fixed payment system, increasing the average length of stay contributes to increased cost without a corresponding increase in reimbursement, thus resulting in a negative correlation between length of stay and operating margin. Other researchers have shown financial problems at hospitals is often partly due to increased average length of stay (Narine et al., 1996). This research supports their findings.

Higher inpatient surgery rates did not show a statistically significant association with operating margins, although the data suggest a negative association. Therefore, it is difficult to comment about the effect of the implementation of NHI on this indicator and its impact on financial effectiveness.

The literature presents no definitive consensus regarding the association of hospital level and size with profitability. Most researchers have suggested that increased size and improved facilities are associated with declining average costs, thus leading to improved financial effectiveness, (Sloan et al., 1983; Becher \& Sloan, 1985; Robinson \& Luft, 1985; Feldstein, 1988; Hoerger, 1991; Williams et al., 1992; Cody et al., 1995; Narine et al., 1996). Other researchers have suggested that increased scale is associated with a decrease in hospital financial effectiveness (Gapenski, 1993). Sear (1992) reported better profitability among hospitals with at least $150-300$ beds. In this study, no significant association was found between scale and level particularly with the adjusted profitability indicators.

Regarding other revenues, researchers in other countries have indicated that uncompensated care increases costs and adversely affects profitability, but these negative impacts can be mitigated by offsetting these costs through other revenue sources (Walker, 1993). This study indicates that an increase to other revenues was positively associated with operating margin, although it was not statistically significant.

Installation of hi-tech equipment indirectly reflects the sophistication of medical technology in the hospital. This research finds that operating margins increased modestly with the installation of moderate amounts of hi-tech equipment, although this correlation was not statistically significant. Other researchers have suggested that, although hi-tech equipment can potentially reduce costs and raise worker productivity, hi-tech equipment cannot replace labor, and therefore tends to increase costs and reduce profitability (Cowing, Holtman, \& Powers, 1983; Coddington et al., 1990). Some researchers have noted that the increased sophistication of medical technology is one of the contributing factors to financial problems at hospitals (Narine et al., 1996).

\subsection{Return on Fixed Assets}

In this study, the regression analysis for regarding return on fixed assets indicates that outpatient revenue, fixed assets ratio, amount of hi-tech equipment, and average length of stay were significantly associated with return on fixed assets. Outpatient revenue was positively associated with return on fixed assets, with every $1 \%$ increase in outpatient revenue as a proportion of total revenue correlating with a $3.9 \%$ increase to return on fixed assets. This finding does not correspond to findings from other countries (AHA, 1981; Hadley, 1982; Urban Institute, 1983; National Center for Health Service Research, 1983).

The fixed assets ratio was significantly and negatively associated with return on fixed assets, with each unit increase to the FA ratio associated with a $3.1 \%$ decrease in return. This contradicts the general expectation that a hospital can increase returns by increasing investment in fixed assets. 
The amount of hi-tech equipment was significantly and positively associated with return on fixed assets. Hospitals having 1 or 2 units of hi-tech equipment installed had a return $1.86 \%$ higher than hospitals with no hi-tech equipment. However, the association failed to attain statistical significance for hospitals with 3 or more units of hi-tech equipment. This finding contradicts research conducted on US hospitals (Narine et al., 1996).

Narine et al. (1996) reported that longer inpatient stays were associated with financial difficulties on the part of the hospitals. Our findings supports this conclusion, with our data showing a significant and negative correlation between average length of stay and return on fixed assets.

Other findings by various studies regarding profitability could not be confirmed in this study. Inpatient surgery rate showed no significant association with return on fixed assets, which was contrary to expectations. Similarly, the data failed to substantiate an expected significant association between hospital level and size and return on assets. Although the literature from western countries suggests that the ratio of debt to total assets is associated with return on total assets (Gapenski, 1993), no association is observed in this study. This could be due to the fact that very few hospitals in the survey carry substantial debt, with inadequate variability in the debt situation failing to yield statistically significant associations. Walker (1993) reported that the other revenue ratio is positively associated with profitability. However, this research failed to confirm or refute this observation, since the positive association failed to attain statistical significance. While several Western researchers have suggested an association between urban-rural location and profitability, our data did not support their findings.

\section{References}

American Hospital Association. (1981). Financially distressed hospital: associated factors (Policy brief 40). Office of Public Policy Analysis.

Becher, E. R., \& Sloan, F. A. (1985). Hospital ownership and performance. Economic Inquiry, 23(1), 21-36. http://doi.org/bgr4g7

Cleverley, W. O., \& Harvey, R. K. (1992). Is there a link between hospital profit and quality? Healthcare Financial Management, 46(9), 44-45. Retrieved from http://www.ncbi.nlm.nih.gov/pubmed/10145680

Cody, M., Friss, L., \& Hawkinson, Z. C. (1995). Predicting hospital profitability in short-termgeneral community hospitals Health Care. Management Review, 20(3), 77-87. Retrieved from http://www.ncbi.nlm.nih.gov/pubmed/7591756

Coddington, D. C., Keen, D. J., Moore, K. D., \& Clarke, R. L. (1990). The crisis in health care: costs, choices and strategies. San Francisco: Jossey-Bass.

Cowing, T. G., Holtmann, A. G., \& Powers, S. (1983). Hospital Cost Analysis: A Survey and Evaluation of Recent Studies. Advance in Health Economics and Health Services Research, 4, 257-303. Retrieved from http://www.ncbi.nlm.nih.gov/pubmed/10299466

Feldstein, P. J. (1988). Health Care Economics. Toronto: John Wiley and Sons.

Gapenski, L. C., \& Vogel, W. B. (1993). The determinants of hospital profitability. Hospital \& Health Services Administration, 38(1), 63-80. Retrieved from http://www.ncbi.nlm.nih.gov/pubmed/10127295

Hoerger, T. J. (1991). Profit variability in for-profit and not-for profit hospitals. Journal of Health Economics, 10, 259-289. http://doi.org/d85rzw

Lin, S. (1994). A Survey Study Of Physician Fee System On 3-Level Teaching Hospitals In Taiwan. Taizhong Shi: Zhongguo yi yao xue yuan, Minguo, 83. Retrieved from http://ndltd.ncl.edu.tw/cgi-bin/gs32/gsweb.cgi/ccd=kt1cFQ/record?r1=3\&h1=0

Narine, L., Pink, G., \& Leatt., P. (1996). Prediction of the financial performance of Ontario hospitals: a test of environmental determinist and adaptationist perspectives. Health Services Management Research, 9, 137-155. Retrieved from http://europepmc.org/abstract/MED/10160278

National Center for Health Services Research. (1983). Characteristics of financially distressed hospitals (Hospital studies program research note3). Rockville Agency for MD: Health Care Policy and Research.

Pike, R. H. (1984). Sophisticated capital budgeting systems and their association with corporate performance. Managerial and Decision Economics, 5(2), 91-97. http://doi.org/br5nv7

Robinson, J. C., \& Luft, H. S. (1985). The impact of hospital market structure on patient volume, average length of stay, and the cost of care. Journal of Health Economics, 4(4), 333-356. http://doi.org/dvtqr3

Sloan, F. A., Feldman, R. D., \& Steinwald, A. B. (1983). Effects of teaching on hospital Costs. Journal of Health 
Economics, 2(1), 1-28. http://doi.org/bqw7xb

Sear, A. M. (1992). Operating characteristics and comparative performance of investorowned multi-hospital systems. Hospital \& Health Services Administration, 37(3), 403-415. Retrieved from http://www.ncbi.nlm.nih.gov/pubmed/10120498

Urban Institute. (1983). Hospitals' financial status in 1980. Washington, DC: The Urban Institute.

Walker, C. L. (1993). A cross-sectional analysis of hospital profitability. Journal of Hospital Marketing, 7(2), 121-138. http://doi.org/fwvr92

Williams, D., Hadley, J., \& Pettengill, J. (1992). Profits, community role, and hospital closure: an urban rural analysis. Medical Care, 30(2), 174-187. Retrieved from http://www.jstor.org/stable/3766060

\section{Copyrights}

Copyright for this article is retained by the author(s), with first publication rights granted to the journal.

This is an open-access article distributed under the terms and conditions of the Creative Commons Attribution license (http://creativecommons.org/licenses/by/3.0/). 